\title{
Rasio legis eksistensi pengadilan tindak pidana korupsi dalam sistem peradilan pidana Indonesia
}

\author{
Ahmad Fauzi ${ }^{1}$, Abdul Madjid ${ }^{2}$, Nurini Aprilianda ${ }^{3}$, Prija Djatmika ${ }^{4}$
}

\begin{abstract}
${ }^{1}$ Ahmad Fauzi; Program Doktor Ilmu Hukum Universitas Brawijaya; Jalan MT. Haryono 169 Malang; 65145; Jawa Timur; Indonesia.

${ }^{2}$ Abdul Madjid; Fakultas Hukum Universitas Brawijaya; Jalan MT. Haryono 169 Malang; 65145; Jawa Timur; Indonesia.

${ }^{3}$ Nurini Aprilianda; Fakultas Hukum Universitas Brawijaya; Jalan MT. Haryono 169 Malang; 65145; Jawa Timur; Indonesia.

${ }^{4}$ Prija Djatmika; Fakultas Hukum Universitas Brawijaya; Jalan MT. Haryono 169 Malang; 65145; Jawa Timur; Indonesia.
\end{abstract}

\begin{tabular}{l} 
A R T I C L E I N F O \\
\hline Article history: \\
Received 2021-01-02 \\
Received in revised form \\
2021-01-19 \\
Accepted 2021-04-01 \\
\hline Kata kunci: \\
Tindak Pidana Korupsi; Pengadilan \\
Tindak Pidana Korupsi; Sistem \\
Peradilan Pidana.
\end{tabular}

Keywords:

Corruption Crime; Corruption Crime Court; Criminal Justice System.

DOI: https://doi.org/10.26905/

idjch.v12i1.5779.

\section{How to cite item:}

Fauzi, A., Madjid, A., Aprilianda, N., Djatmika, P. (2021). Rasio legis eksistensi pengadilan tindak pidana korupsi dalam sistem peradilan pidana Indonesia. Jurnal Cakrawala Hukum, 12(1), 11-20. doi:10.26905/ idjch.v12i1. 5779.

Corresponding Author:

* Ahmad Fauzi.

E-mail address: ahmadfauzi @gmail.com.

\section{Abstrak}

Korupsi jika dibiarkan akan memiliki dampak yang nyata secara ekonomi yakni tidak berimbangnya pendapatan dan meningkatkan kemiskinan Korupsi merupakan permasalahan umum yang terjadi hampir disetiap negara, modus operandi korupsi adalah dengan menggunakan wewenang dan kekuasaan mengambil keuntungan untuk keuntungan pribadi atau pihak ketiga, oleh karena itu untuk menanggulangi kejahatan korupsi dibutuhkan cara untuk menanggulangi kejahtan korupsi. Penelitian ini merupakan penelitian hukum dengan menggunakan pendekatan Normatif sosio. Data yang digunakan adalah data primer dan data sekunder yang dianalisis dengan menggunakan analisis kuantitatif. Aspek utama dalam penanggulangan kejahatan korupsi adalah menggunakan pendekatan penegakan hukum, salah satu pendekatan penegakan hukum adalah dengan meciptakan lembaga Pengadilan Tindak Pidana Korupsi yang diatur dalam Undang-undang No. 46 Tahun 2009 Tentang Pengadilan Tindak Pidana Korupsi sebagai lembaga yang bertugas memeriksa dan memutus perkara tindak pidana korupsi. Kedudukan Pengadilan tindak pidana korupsi sejatinya memiliki legal standing yang kuat dalam sistem peradilan pidana Indonesia, dan keberadaannya sangat penting dan urgent dalam menanggulangi kejahatan korupsi di Indonesia.

\section{Abstract}

Corruption if allowed to have a real economic impact, namely unequal income and increasing poverty Corruption is a common problem that occurs in almost every country, the modus operandi of corruption is to use the authority and power to take 


\section{Jurnal Cakrawala Hukum, Volume 12 No. 1 April 2021}

ISSN PRINT 2356-4962 ISSN ONLINE 2598-6538

advantage for personal gain or third parties, therefore to overcome corruption crimes need a way to tackle corruption crimes. This research is a legal research using the socio-normative approach. The data used are primary data and secondary data which were analyzed using quantitative analysis. The main aspect in tackling corruption crimes is to use a law enforcement approach, one of the approaches to law enforcement is to create a Corruption Crime Court as regulated in Law No. 46 of 2009 concerning the Corruption Crime Court as an institution in charge of examining and deciding cases of criminal acts of corruption. The position of the court for criminal acts of corruption actually has a strong legal standing in the Indonesian criminal justice system, and its existence is very important and urgent in tackling corruption crimes in Indonesia.

\section{Latar Belakang}

Masalah korupsi sudah menjadi masalah umum yang terjadi disemua negara, dalam setiap pembangunan suatu negara korupsi menjadi masalah utama yang harus diatasi penangulangannya, masalah korupsi sebagai issu global ini dinyatakan oleh Dominio bahwa corruption has been a major problem in under development, countries, global issue caled by all country (Dominio, 2011). Oleh Moris kondisi tersebut dinyatakan sebagai corruption block on notion effort, to be prosperios many resorces are taken by people cannot acces may right, As a result, poor people cannot acces many development program and therefull they cannot enhale their life. This leads to horse condition, and the same time the most people live in subsistence level (Moris, 2012).

Korupsi jika dibiarkan akan memiliki dampak yang nyata secara ekonomi yakni tidak berimbangnya pendapatan dan meningkatkan kemiskinan, menurut Tanzy Vito untuk mengindari dampak ekonomi akibat korupsi tersebut maka dilakukan "blased tax system", yakni dengan menyeimbangkan tingkat kesejahteraan antara orang yang kaya dengan orang yang miskin. Konsep blased tax system diuraikan sebagai konsep Favoring the rich and well connected, poor targeting of social program, use of wealth by the well to do lobby goverment for favorable policies than perpetuate inequality in asset ownership, lowes sosial, spending, unequal accuessot education and higer risk in investment decisions for the poor (Vito, 1998).
Konsep korupsi yang dipahami sebagai konsep yang abstrak, bahkan merupakan konsep yang sulit dipahami karena apa yang dimaknai sebagai korupsi di suatu tempat sebagai konsep korupsi akan berbeda dengan konsep korupsi ditempat lain. Oleh Economic Commision For Africa penafsiran yang berbeda berkaitan dengan konsep korupsi di setiap negara disebut sebagai corruption is an exlusive concept because what may be corruption in on society maynot be concidern corruption in another society. what for some traditions and beliefs can be a sign of gratitude, may be concidern bribery in other (Economic Commision For Africa, 2000) sehingga konsep pemahaman teori disuatu tempat akan berbeda dengan tempat lainnya.

Konsep korupsi yang abstrak, maka definisi korupsi disetiap negara memiliki makna dan pengertian yang berbeda-beda. ada yang mendefinisikan sebagai tindakan melanggar hukum, ada yang mendefinisikan sebagai tindakan curang atau bahkan didefinisikan sebagai penyakit psikologis. Oleh Syarun Rozi korupsi disefinisikan sebagai tingkah laku yang menyimpang dari teori tugastugas dari suatu jabatan secara sengaja untuk memperoleh keuntungan berupa suatu kekayaan, atau uang untuk perorangan, keluarga, keluarga dekat atau kepentingan lain (Rozi, 2001). Perbedaan konsep dan definisi tentang korupsi ini oleh Dwiverdi dinyatakan sebagai definition of corruption is dispute because it is varied different society, maka kemudian 


\section{Rasio legis eksistensi pengadilan tindak pidana korupsi dalam sistem peradilan pidana Indonesia}

Ahmad Fauzi, Abdul Madjid, Nurini Aprilianda, Prija Djatmika

tidaklah mudah karena definisi korupsi itu berbeda-beda bergantung kepada masing-masing masyarakat (Dwiverdi, 1999).

Adapun titik fokus dari perilaku korupsi adalah apabila pemangku kepentingan publik mencoba mengambil keuntungan secara pribadi atau mengejar kepentingan dan keuntungan secara politik dalam menjalankan tugas-tugasnya, seperti dijelaskan oleh Economic Commision For Africa yang menyatakan corruption generally occurs when public officials or officers try to obtain a personal financial or political benefit in exchange for not pursuing, or selectively pursuing, a public duty (Economic For Africa, 2000).

Tindakan korupsi ini dapat dikategorikan sebagai tindakan penyimpangan dengan menggunakan sarana suap dan bantuan kepada pihak ketiga sebagai modusnya, bentuk tindakan korupsi dengan penyimpangan dan menggunakan suap serta pihak ketiga oleh Max Weber disebutkan sebagai gejala korupsi yang terjadi di negara modern, oleh Weber disebutkan in the modern state, publick affairs are no longger considered as source of income to be exploited for rent. Kritik Weber menegaskan bahwa perilaku abuse of power dari pemang$\mathrm{ku}$ kepentingan untuk tujuan pribadi dan keuntungan pribadi yang dianalogikan sebagai "menerbitkan urusan sendiri" merupakan bukan sumber pendapatan yang dapat diterima secara sah tetapi merupakan suatu tindakan korupsi (Weber, 1969).

Bahwa pendekatan terhadap kejahatan korupsi harus dilakukan dengan cara memahami korupsi sebagai penyakit masyarakat tanpa ada pengecualian, tindakan korupsi dilakukan dengan cara mengambil keuntungan pribadi dengan modus menguntungkan diri sendiri atau pihak ketiga. Hal tersebut yang dapat dilakukan dengan cara merubah sistem organisasi, penyerdehanaan sistem birokrasi dan perubahan sistem gaji serta cara apapun yang efektif untuk menanngulangi kejahatan korupsi.
Cara penanggulangan korupsi dengan metode penegakan hukum merupakan salah satu cara yang efektif selain juga memperbaiki perilaku manusia untuk menghindari tindakan korupsi, oleh karenanya mengedepankan penangulangan korupsi dengan sarana penegakan hukum haruslah lebih awal dibandingkan dengan implementasi kebijkan lainnya. Oleh Buscaglia pendekatan ini dinyatakan sebagai the growth and decine of systemic corruption is also subject to law and behavior, we must better define the law before implementation publick policy (Buscaglia, 1995).

Dalam menanggulangi kejahatan korupsi maka pendekatan dengan metode penegakan hukum untuk menanngulangi keorupsi dapat dilakukan dengan cara (Stephenson, 2016): 1. Diagnotic analysis within a country indentifying within a priority list, the main istitutional area where systemic corruption area; 2. Develope a date base for each of these institution containing objective an subjective measures of corruption; 3 . Conduct analysis with in clear identification of the factors cousing corruption in a goverment agency; 4. Making anti corruption policies and agency. Keempat lagkah tersebut, secara khusus dalam menanggulangi kejahatan korupsi dapat menggunakan perangkat Agency atau lembaga.

Menurut Buscaglia pengadilan tindak pidana korupsi merupakan salah satu aspek penting dan efektif untuk menekan angka korupsi, hal tersebut dinyatakan sebagai aplied judicial and municipal levels in many country with in significant result (Buscaglia, 1995). Suatu lembaga pengadilan tindak pidana juga diharapkan memiliki aspek penting untuk disebut sebagai badan pengadilan tindak pidana korupsi yakni (Gambeta, 1993): 1. A higher concentration of internal organizational roles concentrated in the hand of fin the hand of fewer decision maker within the court; 2. The added number and complexcity of the procedurals steps parency followed with the court; 3 . The greater uncertainty related to the prevailing doctrine, laws and regulations; 4 . Fewer alternative souces of dispute resoluion; 5. Fresence od organized crime groups. 


\section{Jurnal Cakrawala Hukum, Volume 12 No. 1 April 2021}

ISSN PRINT 2356-4962 ISSN ONLINE 2598-6538

Kelima aspek diatas merupakan suatu bentuk kemampuan lembaga pengadilan tindak pidana korupsi sebagai suatu lembaga yang secara khusus menanggulangi kejahatan korupsi, kemampuan lembaga pengadilan tindak pidana korupsi ini menurut Robert Klitgard adalah merupakan salah satu cara menanggulangi korupsi yang masuk kedalan mekanisme Neo Institution Economic Frame.

Menurut Klitgard penanggulangan korupsi dapat dilakukan dengan cara: (Klitgard, 1998) 1. Principal Aggent or Agency Models, Yaitu penanganan tindak pidana korupsi dengan menggunakan model kepemimpinan diktator, dimana pemimpin diktator memerintahkan kepada para pegawai untuk berkomitmen untuk menolak setiap tindakan yang menguntungkan diri sendiri atau pihak ketiga; 2. New Publick Management Persfective, Model ini dilakukan dengan 4 (empat cara), yakni: a. Mengurangi jumlah transaksi keuangan dan membatasi setiap transaksi keuangan; $b$. Mengurangi keuntungan dari setiap transaksi keunagan; c. Mempermudah dan mempercepat akses deteksi praktek korupsi; d. menjatuhkan hukuman bagi pelaku korupsi; 3. Neo Institution Economic Frame, pemerintah harus menghindari adanya praktek monopoli dan mewaspadai pera pejabat pemerintahan untuk melakukan kejahatan korupsi, model ini mengharuskan bentuk administrasi baru atau reformasi birokrasi dilakukan secara bersamaan dengan mengubah undang-undang dengan semangat anti korupsi.

Adapun pelaksanaannya dilakukan dengan 3 (tiga) cara: a. Memberikan pengertian dan batasan korupsi dalam produk undang-undang; $b$. Memberikan pelimpahan tanggung jawab dengan penugasan sementara; $c$. Pengendalian atau kontrol oleh lembaga hukum/Pengadilan; d. partisipasi masyarakat terhadap kinerja birokrasi melalui mekanisme civil policy.

World Bank menjelaskan pembentukan lembaga peradilan korupsi juga merupakan sarana bagi suatu negara agar mampu keluar dari kemiskinan, adapun cara-cara yang dapat dilakukan un- tuk menindak kejahatan korupsi dapat dilakukan dengan cara (World Bank, 2005): 1. Competitive Private Sector: Dilakukan dengan sarana peraturan hukum, dimana pertauran hukum ini bertujuan untuk menyederhanakan peraturan, stabilitas aturan hukum dengan cara mengurangi praktek monopoli; 2. Political Acuntability: Kopetensi politik dan ekonomi yang sehat, terintegrasi kebijakan hukum dan pengumuman harta kekayaan para pejabat negara; 3. Civil Society: Dilakukan dengan publik hearing dari setiap kebijakan-kebijakan yang akan diputuskan oleh pemerintah; 4 . Institution Resistaint of Power: Dilakukan dengan cara pengadilan yang independent; 5. Public Sector Management: Memberikan kinerja yang profesionalitas kepada masyarakat dengan pelayanan yang prima.

Penjelasan diatas maka dapat dipahami bahwa penindakan kejahatan korupsi dengan sarana hukum dan badan peradilan merupakan langkah institution resistaint of power untuk menanggulangi korupsi. Bagaimana eksistensi pengadilan tindak pidana korupsi dalam sistem peradilan pidana Indonesia. Apa urgensi pengadilan tindak pidana korupsi di Indonesia dalam sistem peradilan pidana Indonesia.

\section{Metode}

Metode Penelitian dalam penulisan artikel ini adalah metode penelitian doctrinal atau biasa disebut dengan penelitian hukum normatif. Penelitian ini merupakan penelitian hukum dengan menggunakan pendekatan normatif-sosio. Data yang digunakan adalah data primer dan data sekunder yang dianalisis dengan menggunakan analisis kuantitatif.

\section{Pembahasan}

\subsection{Eksistensi pengadilan tindak pidana korupsi dalam sistem peradilan pidana}

Pembahasan mengenai penegakan hukum pidana pada prinsipnya hanya berbicara pada dua 


\section{Rasio legis eksistensi pengadilan tindak pidana korupsi dalam sistem peradilan pidana Indonesia}

Ahmad Fauzi, Abdul Madjid, Nurini Aprilianda, Prija Djatmika

aspek saja yaitu faktor efektifitas dan keadilan dari berjalannya sistem peradilan pidana, sistem peradilan pidana berjalan efektif jika kemampuan dan ketepatan serta akurasi dalam mendeteksi, investigasi, penyidikan, penyelidikan, penuntutan, pemeriksaan dan putusan pengadilan serta penjatuhan hukuman kepada terdakwa yang dinyatakan bersalah sampai dengan tingkat pelaksanaan hukuman pidana.

Keadilan dalam suatu proses sistem peradilan pidana hanya berpijak pada enam unsur saja, dimana unsur tersebut umum dikenal sebagai "effect prosedural" sebagaimana dikemukakan oleh Konovsky dan Folger yaitu (Konovsky, 1991): 1. Konsistensi penerapan standat-standar (aturan hukum) kepada siapapun dan sepanjang waktu; 2 . Proses penegakan hukum tidak bias oleh kepentingan pribadi; 3 . Akurasi keputusan hukum yang diputuskan berdasarkan informasi dan fakta (alat bukti) yang mencukupi; 4. Dapat dikoreksi, artinya dapat diperdebatkan dan dan dibanding (mekanisme perlawanan hukum berupa Banding, Kasasi, Peninjauan Kembali); 5. Refresentasi semua hal yang terlibat di dalamnya (tangggung jawab hukum dan moral bagi aparat yang terlibat didalamnya); 6. Terpenuhinya standar etika dari semua elemen yang terlibat di dalamnya. Oleh karenannya apabila keenam unsur diatas terpenuhi maka akan menciptakan keadilan prosedural, yang akan berakibat pada terciptanya sistem peradilan pidana yang legitimasi dan berwibawa (Bias, 1986).

Keadilan prosedural ini juga memandang bahwa terhadap hal-hal dari keputusan hukum dari sistem peradilan pidana yang tidak adil bisa diterima asalkan dapat dipersepsikan oleh masyarakat sebagai suatu proses yang "fairness" (Greenberg, 1987). Sistem hukum pidana diperlukan dalam menegakan sanksi pidana, tentu saja penanggulangan tindak pidana dalam sistem peradilan pidana dilakukan dengan menggunakan sarana penal, penggunaan saran penal dimaksudkan untuk membuat atau merumuskan suatu perundangundangan yang baik yang erat dengan kebijakan kriminal (Kaligis, 2006), dimana kebijakan kriminal ini dalam sistem hukum pidana bentuknya yakni berupa penjatuhan pidana dan kriteria kriminalisasi. Kedua hal tersebut tentu saja menggunakan sarana penal dalam sistem peradilan pidana yang berfungsi untuk menentukan kriteria (Muladi, 2005): 1. Perbuatan apa saja yang seharusnya dijadikan tindak pidana; 2. Sanksi apa saja yang dapat dikenakan kepada si pelanggar.

Menurut Gadner sistem peradilan pidana dijelaskan sebagai the methods by which a society deals with those who are accussed of having commited crime, yakni sebuah metode dimana masyarakat berurusan dengan mereka yang dituduh melakukan kejahatan (Gadner, 2000), dalam implemtasinya sistem peradilan pidana berfungsi untuk melindungi masyarakat dalam melakukan pengelolaan sistem ketertiban umum dan mencegah adanya kejahatan. Adapun akan hal tersebut akan ada erat kaitannya dengan sistem sosial apa yang menjadi penyebab kejahatan, mencegah kejahatan dan interaksi atas hal tesebut semua (Purwoleksono, 2010).

Dalam sistem peradilan pidana merupakan sebuah rangkaian sistem yang terjalin utuh untuk kemudian mengoperasionalkan hukum pidana sebagai sarana utama, yakni menegakan hukum pidana materiil dan hukum pidana formil (Yesmil, 2009). Dalam menjalankan fungsi dan perannya maka kemudian sistem peradilan pidana ditunjang oleh lembaga yang menjadi elemen utamanya yakni, lembaga kepolisian, kejaksaan, pengadilan dan lembaga pemasyarakatan. Kesemua lembaga ini bekerja secara terkait untuk menanggulangi kejahatan (Atmasasmita, 1996).

Bahwa atas pendapat tersebut diatas, kiranya dalam sistem peradilan pidana di Indonesia selain komponen kepolisian, kejaksaan, pengadilan dan lembaga pemasyarakatan ada juga komponen lain diluar keempat komponen dalam sistem peradilan pidana tersebut yang memiliki kewenangan sebagai komponen penegak hukum. 
Menempatkan Pengadilan tindak pidana korupsi dalam sistem peradilan pidana merupakan salah satu cara untuk memperkuat upaya pemberantasan korupsi, hal tersebut merupakan amanat dari konvensi penaggulangan tindak pidana korupsi (UNCAC) yang menjadi landasan utama dalam penaggulangan tindak pidana korupsi baik secara hukum materiil dan hukum formil.

Dalam Ketentuan Pasal 36 Konvensi UNCAC dinyatakan bahwa adanya pertanggung jawaban hukum yang disebut sebagai pertanggung jawaban "legal Person", Bahwa berkaitan dengan ketentuan Pasal Pasal 36 UNCAC yang menyatakan bahwa "Harus ada suatu badan atau badan-badan khusus dalam memerangi melalui penegakan hukum", maka badan ini merupakan badan yang tetap dan permanen yang harus diberi kebebasan agar dapat menjalankan fungsi-fungsinya secara efektif dan tanpa pengaruh apapun.

Atas Konvensi penanggunangan korupsi dalam UNCAC tersebut maka Indonesia sebagai negara peserta melakukan ratifikasi dengan Undang-Undang No. 7 tahun 2006 Tentang Ratifikasi pengesahan United Nations Convention Againts Corruption 2000 yang kemudian dalam pelaksanaannya diatur dengan aturan: 1 . Undangundang No. 31 tahun 1999 tentang Tindak Penyelenggraan negara yang bersih dan bebas dari Korupsi, kolusi dan nepotisme yang isinya adalah menserasakan dan mendukung sikap anti koruspsi dalam konvensi UNCAC; 2 . Undang-undang No. 30 Tahun 2002 Tentang komisi pemberantasan korupsi, yang dalam ketentuan Pasal 52 menyatakan "Pengadilan Tipikor berada di lingkungan peradilan umum.

Berdasarkan ketentuan Pasal ini maka awalnya pengadilan tindak pidana korupsi tidak dibentuk dalam undang-undang tersendiri tetapi merupakan satu paket dengan pembentukan Komisi Pemberantasan Korupsi (KPK), Pengadilan Tindak pidana korupsi hanya memeriksa dan memutus tindak pidana korupsi yang penuntutannya diajukan oleh Komisi Pemberantasan Korupsi saja. Perkara-perkara korupsi yang dituntut oleh Jaksa Penuntut Umum dari Kejaksaan tetap diadili oleh pengadilan negeri biasa.

Pengadilan Tipikor hanya memeriksa dan memutus tindak pidana yang penuntutannya diajukan oleh Komisi Pemberantasan Korupsi, sedangkan perkara yang diajukan oleh Jaksa Penuntut Umum dari Kejaksaan tetap diperiksa dan diputus di Pengadilan negeri maka terdapat dua alur pemeriksaan tindak pidana korupsi oleh pengadilan. Jika perkara korupsi di pengadilan negeri dilakukan oleh seluruhnya hakim karier, maka majelis hakim di Pengadilan Tindak Pidana Korupsi terdiri atas dua hakim karier dan tiga hakim ad hoc yang direkrut dari masyarakat sehingga dianggap tidak terpengaruh hirarki atau administrasi kepegawaian. Tentu saja ini akan menjadi dualisme dalam memutus perkara tindak pidana korupsi, untuk memutus dualisem tersebut maka Pengadilan Tindak pidana Korupsi yang disahkan berdasarkan Undang-undang No. 46 Tahun 1999 tentang pengadilan tindak pidana korupsi menjadi solusi untuk menghilangkan $d u$ alism penanganan perkara tindak pidana korupsi.

\subsection{Urgensi pengadilan tindak pidana korupsi dalam sistem peradilan pidana Indonesia.}

Pengadilan Tindak Pidana Korupsi di Indonesia keberadaan diawali dari adanya ketidakpercayaan masyarakat terhadap peradilan umum yang memeriksa dan memutus perkara korupsi, vonis yang rendah, penanganan yang tidak transparan dan rendahnya integritas aparat hukum menjadi masalah utama yang dihadapi dalam menanggulangi korupsi di Indonesia. Oleh Daniel Kaufman dinyatakan bahwa tingkat korupsi di badan peradilan di Indonesia memiliki angka yang tinggi, terutama berkaitan dengan praktek suap dilingkungan aparat pengadilan. Adapun modus operandinya ialah suap untuk melancarkan 


\section{Rasio legis eksistensi pengadilan tindak pidana korupsi dalam sistem peradilan pidana Indonesia}

Abmad Fauzi, Abdul Madjid, Nurini Aprilianda, Prija Djatmika

perkara atau memperingan vonis yang akan dijatuhkan kepada pelaku korupsi, oleh karenanya maka lembaga peradilan merupakan lembaga yang paling tinggi tingkat inisiatif untuk meminta suap (Lubis, 1998).

Kondisi ini semakin rumit ketika lembaga peradilan tersebut juga tidak terlepas dari adanya praktek mafia peradilan yang dapat mengatur berat atau ringgannya vonis bagi pelaku korupsi, kedua masalah rendahnya integritas hakim dalam memutus perkara korupsi sehingga menghasilkan hakim yang rawan suap dan hakim yang memutus dengan vonis ringan bagi pelaku korupsi. ketiga adalah kemampuan pengetahuan hakim terhadap kejahatan korupsi yang berkaitan dengan tindak pidana pencucian uang (money laundring) dan kejahatan lainnya, tentu saja ketiga hal ini sangat berpengaruh terhadap kualitas dan vonis yang dijatuhkan hakim yang memang kurang memuaskan aspek keadilan masnyarakat (Syarifudin, 1998).

Hadirnya pengadilan tindak pidana korupsi sebagaimana diatur dalam Undang-Undang No. 46 Tahun 2009 tentang Pengadilan Tindak Pidana Korupsi merupakan hal yang mendesak untuk dibentuk guna kepentingan untuk memeriksa dan memutus perkara korupsi yang jumlahnya terus meninggkat, selain itu juga berkaitan dengan ifisiensi dan kesederhanaan dalam proses menangani perkara korupsi serta rendahnya produktivitas aparat dalam menangani perkara korupsi di Indonesia (Komisi Hukum Nasional, 2002). Pembentukan pengadilan khusus tindak pidana korupsi dimaksudkan agar penanganan perkara korupsi dilakukan dengan cara yang cepat dan berbeda dengan mekanisme penanganan perkara pada peradilan umum, meknisme dengan cara cepat ini dilakukan sebagai jalan pintas yang cepat (shortcut) untuk menjawab kelemahan-kelemahan di pengadilan konvensional. Dimana pengadilan konvensional memiliki kekurangan berupa minimnya kualitas dan itegritas hakim dan proses peradilan yang tidak akuntabilitas (Tim Pengarah
Pengadilan Niaga dan Pembentukan Pengadilan Tindak Pidana Korupsi, 2004).

Pengadilan tindak pidana korupsi juga sejalan dengan Pasal 36 UNCAC yang menyatakan each state party shall, in accordancewith the fundamental principles of its legal system, ensure the existence of a body or bodies or persons specialized in combating corruption though law enforcement. such a body or bodies or person shall be granted the necessary independence, in accordance with the fundamental principles of the legal system of the state party, tobe able to carry out their fuction effectively and without any undue (influence) (pressure). Such person or staff of such body or bodies should have the appropriate training ang resources to carry out their tasks (Ganarsih, 2009).

Pengadilan Tindak Pidana Korupsi yang dibentuk berdasarkan ketentuan Pasal 53 UndangUndang Nomor 30 Tahun 2002 tentang Komisi Pemberantasan Tindak Pidana korupsi tersebut diamanatkan oleh Mahkamah melalui putusan Nomor 012-016-019/PUU-IV/2006 tanggal 19 Desember 2006 yang dalam amar putusannya menyatakan bahwa ketentuan Pasal 53 UndangUndang Nomor 30 Tahun 2002 tentang Komisi Pemberantasan Tindak Pidana Korupsi bertentangan dengan Undang-Undang Dasar 1945 dan menyatakan Pasal tersebut tidak lagi mempunyai kekuatan hukum yang mengikat.

Putusan Mahkamah Konstitusi Nomor 012016-019/PUU-IV/2006 tanggal 19 Desember 2006 diajukan oleh pemohon Judicial Review atas nama Mulyana W Kusuma, dkk serta Capt. Tarsicius Walla. Dualisme tersebut terjadi karena dalam perkara tindak pidana korupsi dimana penuntutan yang dilakukan oleh Komisi Pemberantassan Korupsi (KPK) proses persidangan, pemeriksaan dan putusan dilakukan oleh Pengadilan Tindak pidana korupsi. Sementara perkara tindak pidana yang penuntutan yang dilakukan oleh Kejaksaan proses persidangan, pemeriksaan dan putusan dilakukan di Pengadilan Negeri. Oleh Mahkamah Konstitusi dualism ini bertentangan dengan prinsip 
konstitusi yang secara prinsip menjamin setiap orang mendapat perlakuan yang sama di hadapan hukum, juga telah menimbulkan ketidakpastian hukum serta merugikan hak konstitusional pemohon.

Secara prinsip pembentukan pengadilan tindak pidana korupsi telah sesuai dengan ketentuan Pasal 15 ayat (1) Undang-Undang Nomor 4 Tahun 2004 tentang Kekuasaan Kehakiman. Jika dilihat dalam pertimbangan putusannya Mahkamah Konstitusi menyatakan bahwa Komisi Pemberantasan Korupsi (KPK) saat itu yakni sebagaimana diatur dalam Undang-Undang Nomor 30 Tahun 2002 tentang Komisi Pemberantasan Tindak Pidana Korupsi mengharuskan adanya pembentukan pengadilan Tindak Pidana Korupsi untuk mengadili perkara tindak pidana korupsi. Dalam Pasal 53 ayat (1) dan ayat (2) Undang-Undang tersebut menentukan bahwa Pengadilan Tindak Pidana Korupsi berada di bawah peradilan umum, dan untuk pertama kali, akan dibentuk di Pengadilan Negeri Jakarta Pusat. Dalam Pasal 53 ayat (3), ditentukan bahwa pembentukan Pengadilan Tindak Pidana Korupsi selanjutnya dilakukan secara bertahap dengan Keputusan Presiden.

Putusan yang diambil oleh Mahkamah jangan sampai menyebabkan timbulnya ketidakpastian hukum (rechtsonzekerheid) yang dapat mengakibatkan kekacauan dalam penanganan atau pemberantasan tindak pidana korupsi. Putusan Mahkamah juga tidak bermaksud untuk melemahkan semangan (disinsentive) pemberantasan korupsi yang telah menjadi musuh bersama bangsa dan masyarakat Indonesia.

Walaupun Putusan Mahkamah Konstitusi pada dasarnya hanya menyangkut ketentuan Pasal 53, namun secara substansial putusan tersebut juga berpengaruh pada keseluruhan ketentuan dari Pasal 53 sampai dengan Pasal 62 Undang-Undang Nomor 30 Tahun 2002 tentang Komisi Pemberantasan Tindak Pidana Korupsi yang secara prinsip mengatur mengenai hukum acara pemeriksaan di sidang pengadilan. Oleh karena itu, Mahkamah Konstitusi dalam putusannya juga meminta pembentuk undang-undang untuk sesegera mungkin dan paling lama 3 (tiga) tahun sejak putusan Mahkamah Konstitusi dibacakan harus telah melakukan penyelarasan Undang-Undang Nomor 30 Tahun 2002 tentang Komisi Pemberantasan Tindak Pidana Korupsi dengan UndangUndang Dasar Negara Republik Indonesia Tahun 1945 dan rnembentuk Undang-Undang tentang Pengadilan Tindak Pidana Korupsi dengan undangundang tersendiri.

Pengadilan Tindak Pidana Korupsi mempunyai proses khusus dalam pelakasanannya, atas hal ini Mahkamah Konstitusi mempertimbangkan perlunya menyediakan waktu bagi proses peralihan yang mulus (smooth transition) untuk terbentuknya aturan yang baru. Putusan Mahkamah Konstitusi dalam perkara tersebut bersifat final dan mengikat.

Secara filosofis Putusan Mahkamah Konstitusi juga telah memberikan pembenaran secara konstitusional yang diperlukan dalam pemberantasan korupsi. Dengan demikian, agenda pemberantasan korupsi melalui lembaga khusus antikorupsi yaitu Komisi Pemberantasan Korupsi serta Pengadilan Tindak Pidana Korupsi memperoleh penguatan legitimasinya secara juridis konstitusional dan memberikan landasan yuridis dan konstitusional bagi keberadaan Pengadilan Tindak Pidana Korupsi yang sejalan dan sesuai dengan Undang-Undang Dasar Negara Republik Indonesia Tahun 1945. Sehingga dapat memberikan landasan yang kokoh bagi Pengadilan Tindak Pidana Korupsi agar memiliki kewenangan dalam memeriksa, mengadili, dan memutus perkara tindak pidana korupsi yang penuntutannya diajukan baik oleh Komisi Pemberantasan Korupsi maupun Kejaksaan

Pembentukan Pengadilan tindak pidana korupsi sejalan dengan Konvensi Perserikatan Bangsa-Bangsa Menentang Korupsi Tahun 2003 yang telah diratifikasi Indonesia mengatur secara 


\section{Rasio legis eksistensi pengadilan tindak pidana korupsi dalam sistem peradilan pidana Indonesia \\ Ahmad Fauzi, Abdul Madjid, Nurini Aprilianda, Prija Djatmika}

komprehensif dan tegas mengenai kewenangan, hakim dan susunan majelis hakim, hukum acara khusus yang digunakan dalam pemeriksaan di sidang Pengadilan Tindak Pidana Korupsi.

Pembentukan pengadilan tindak pidana korupsi juga harus mengikuti prinsip-peradilan secara universal yakni: lndependensi dan Tidak Memihak (Impartial). Prinsip independensi dan tidak memihak merupakan prinsip utama yang telah ditentukan dalam konstitusi dan berbagai ketentuan hukum international. Prinsip independensi menghendaki agar institusi peradilan bebas dan merdeka dari campur tangan (intervensi), tekanan dan paksaan, baik secara langsung maupun tidak langsung dari pihak-pihak lain di luar pengadilan sehingga dalam setiap memutus suatu perkara semata-mata hanya dilakukan demi keadilan berdasarkan hukum dan keyakinan hakim.

Prinsip independensi berkenaan dengan independensi secara personal (hakim) atau secara kelembagaan. Hal ini tidak terlepas dari pengaturan yang berhubungan dengan pengangkatan dan pemberhentian hakim, anggaranlkeuangan pengadilan, dan lain-lain. Sedangkan prinsip tidak memihak pada dasarnya bahwa hakim dalam mengadili tidak boleh membeda-bedakan dan menghargai secara adil dan seimbang hak-hak para pihak yang berperkara, sehingga seorang hakim harus terbebas dan terhindar dari benturan kepentingan (conflict of interest).

Sederhana dan Cepat adalah merupakan hak yang dituntut publik ketika memasuki proses peradilan adalah memperoleh kemudahan akses yang didukung sistem. Proses yang berbelit-belit mungkin akan menimbulkan ketidakadilan, untuk itu tindakan prosedural yang mudah, sederhana, cepat, dan ketelitian dalam pengambilan keputusan harus menjamin terciptanya keadilan. Oleh karena itu, proses di pengadilan harus dibuat sedemikian rupa secara sederhana, baik dari segi biaya, lokasi, dan prosedur sehingga tidak menghalangi hak seseorang untuk memperoleh keadilan (access to justice). Proses di pengadilan yang harus ditempuh para pencari keadilan, diharapkan tidak memerlukan waktu yang lama. Dengan kata lain, proses pengadilan haruslah cepat, jelas, dan tepat waktu. Proses yang lama dan tidak jelas limitasi waktunya, tidak hanya membuat pesimisme para pencari keadilan, tetapi juga mengundang kecurigaan atau dugaan yang bersifat negatif.

Transparansi disini adalah bukanlah keterbukaan yang tanpa batas, tetapi bermaksud memberikan kesempatan bagi publik untuk melakukan kontrol dan koreksi sesuai dengan tingkat pemeriksaan dan kebutuhan, misalnya, putusan diucapkan dalam sidang terbuka untuk umum dan keterbukaan putusan pengadilan yang dapat diakses oleh publik untuk dapat mengetahui landasan diambilnya suatu keputusan.

Pemberian kekuasaan membawa konsekuensi adanya akuntabilitas dan dalam kerangka pelaksanaan akuntabilitas ada beberapa hal yang harus diperhatikan, yaitu adanya: ketaatan pada hukum; prosedur yang jelas; adil dan layak; mekanisme kontrol yang efektif. Semua prinsip tersebut menjadi ukuran sejauh mana sistem peradilan telah dilaksanakan dengan baik. Semua prinsip umum di atas, tidak terlepas dengan independensi kekuasaan kehakiman yang berimpit dengan akuntabilitas yang didalamnya terdapat akuntabilitas politik, akuntabilitas putusan, dan akuntabilitas perilaku termasuk administrasi pengadilan Tindak Pidana Korupsi itu sendiri.

\section{Simpulan}

Bahwa eksistensi pengadilan tindak pidana korupsi sebagaimana diatur dalam Undangundang No. 46 Tahun 2009 tentang Pengadilan Tindak Pidana Korupsi merupakan suatu bentuk pengadilan yang berdiri sebagai pengadilan khusus yang bertugas dan diberi wewenang untuk memeriksa dan memutus perkara tindak pidana korupsi dalam sistem peradilan pidana Indonesia, 


\section{Jurnal Cakrawala Hukum, Volume 12 No. 1 April 2021}

ISSN PRINT 2356-4962 ISSN ONLINE 2598-6538

adapaun maksud dan tujuan dibentuknya pengadilan tindak pidana korupsi ini untuk menanggulangi kejahatan korupsi yang terjadi ditiap negara berdasarkan rekomendasi Pasal 36 Konvensi UNCAC.

Adapunn urgensi dibentuknya pengadilan tindak pidana korupsi dikarenakan ketidakpercayaan masyarakat terhadap penanggulangan kejahatan korupsi dengan sarana mekanisem pengadilan konvensional yang kurang memiliki integritas dan putusannya kurang memenuhi rasa keadilan masyarakat, adapun juga keberadaan pengadilan tindak pidana korupsi diharapkan menjadi sebagai jalan pintas yang cepat (shortcut) untuk menjawab kelemahan-kelemahan di pengadilan konvensional. Dimana pengadilan konvensional memiliki kekurangan berupa minimnya kualitas dan itegritas hakim dan proses peradilan yang tidak akuntabilitas.

\section{Daftar pustaka}

Ardiansyah, D., 2017. Pencabutan hak untuk memilih dan dipilih bagi terpidana tindak pidana korupsi. Jurnal Cakrawala Hukum, 8(2), pp.139-148.

Atmasasmita, Romli. 1996. Sistem Peradilan Pidana (Criminal Justice System) Perspektif Eksistensialisme dan Abolisionalisme. Bina Cipta. Jakarta.

Buscaglia, Edgardo. Rattliff, William. Dakolias, Maria. 1995. Judicial Reform in Latin america, A Framework For National Development. Hoover University and Stanford University.

Dominio. Pyliris, Robert Orttug. Growth, Publick. 2011. Investment and Corruption with falling institution. Economic Goverment Journal, Vol. No. 187.

Dwiverdi, et. al. 1999. Challenges And Aproaches Combating Corruption In India, Routledge. Oxford University.

Economic Commision For Africa. Deepening The Judiciary Effectiveness in Combating Coruuption, ECA Publications and Conference Management Section. Addis Abba Eithopia.
Gambeta, Diego. 1993. The Sicilian Mafia, Cambridge. MA, Harvard University Press.

Ganarsih, Yenti. 2009. Paradigma baru dalam pengaturan anti korupsi. Jurnal Hukum Prioris, Volume 2 Nomor 3, September.

Klitgard, Robert. 1998. Controling Corruption. University Calofornia Press. Berkeley California.

Komisi Yudisial Republik Indonesia. 2018. Meluruskan Arah Manajemen Kekuasaan Kehakiman. Sekertarian Jenderal Komisi Yudisial Republik Indonesia. Jakarta.

Puspito, Nandang T (Editor). 2011. Pendidikan AntiKorupsi Untuk Perguruan Tinggi, Kementerian Pendidikan dan Kebudayaan Republik Indonesia. Direktorat Jenderal Pendidikan Tinggi Bagian Hukum Kepegawaian. Jakarta.

Rozi, Syafrun. 2001. Menjinakan Korupsi di Indonesia. Jurnal Lipi. Vol 3.

Stephen, Moris D. 2012. Corruption, Drug Traficking And Violance in Mexico. the Brown Journal of World Affair. Vol XVIII Issue II.

Stephenson, Matthew C. 2016. Speciallised Anti corruption Court, A Comparative Mapping, Anti Corruption Rescue Centre, V. 4 Issue, No. 7, Desember.

Supriyadi, S., 2015. Peran DPRD dalam pencegahan korupsi kolusi dan nepotisme di daerah. Jurnal Cakrawala Hukum, 6(2), pp.228-238.

Syarifudin, dkk. 2006. Benang Kusust Peradilan Korupsi Perbankan. KRHN. Jakarta.

Vito, Tanzy. 1998. Corruption Around The World, Causes, Consequences, Scope and Cases. IMF Staff Paper Journal. Vol 44, No 4.

Weber, Max. 1969. Economy and Society III. Bedminster. New York.

Yulianto, Y., 2020. Politik hukum revisi undang-undang KPK yang melemahkan pemberantasan korupsi. Jurnal Cakrawala Hukum, 11(1), pp.111-124. 